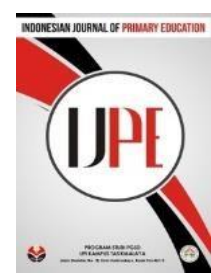

\title{
Pengaruh Metode Scramble dan Minat Baca terhadap Kemampuan Membaca Pemahaman Siswa Sekolah Dasar
}

\author{
Dika Zuchdan Sumira ${ }^{1}$, Deasyanti ${ }^{2}$, Tuti Herawati ${ }^{3}$ \\ ${ }^{1}$ Program Pascasarjana Universitas Negeri Jakarta, Jl. Rawamangunmuka ,Jakarta Timur \\ ${ }^{2}$ Program Pascasarjana Universitas Negeri Jakarta, Jl. Rawamangunmuka ,Jakarta Timur \\ ${ }^{3}$ Program Pascasarjana Universitas Negeri Jakarta, Jl. Rawamangunmuka ,Jakarta Timur \\ *Corresponding author: dikazuchdan21@gmail.com ; deasy.edupsy@yahoo.com ; tutiherawati2@yahoo.co.id
}

Diterima 6 Mei 2018; Direview 9 Mei 2018; Diterima 17 Mei 2018

Diterbitkan online 4 Juni 2018

\begin{abstract}
Abstrak
Tujuan dari penelitian ini adalah untuk mengetahui pengaruh metode scramble terhadap kemampuan membaca pemahaman ditinjau dari minat baca siswa sekolah dasar. Penelitian dilakukan di SD Negeri 1 Kawali dengan sampel siswa kelas IVA 30 orang sebagai kelas eksperimen dan kelas IV B dengan sampel siswa 30 orang sebagai kelas kontrol yang dilaksanakan pada tahun ajaran 2017/2018. Penelitian menggunakan treatment by level $2 \times 2$. Teknik analisis data adalah analisis varians dua jalur (ANAVA). Hasil penelitian menunjukan bahwa (1) terdapat perbedaan kemampuan membaca pemahaman siswa yang melalui metode scramble dengan siswa yang menggunakan metode ekspositori; (2) terdapat interaksi antara metode pembelajaran dan minat baca terhadap kemampuan membaca pemahaman siswa sekolah dasar; (3) Siswa yang memiliki metakognisi belajar tinggi, kemampuan pemecahan masalah matematika antara kelompok siswa yang diajar metode scramble lebih tinggi dari pada kelompok siswa yang diajar menggunakan metode ekspositori; (4) Siswa yang memiliki minat baca rendah, kemampuan membaca pemahaman antara kelompok siswa yang diajar menggunakan metodel scramble lebih rendah dari pada kelompok siswa yang diajar menggunakan metode ekspositori.
\end{abstract}

Kata Kunci: Metode, Scramble, Membaca, Pemahaman, Minat Baca.

\section{PENDAHULUAN}

Proses pendidikan yang dilaksanakan di sekolah mengharapkan siswa dapat mengembangkan potensi terbaiknya sesuai dengan tujuan pembelajaran. Guru sebagai pengajar bukan hanya sekedar menyampaikan informasi terkait dengan materi pembelajaran, akan tetapi harus mampu menciptakan suasana kelas yang menyenangkan supaya siswa terlibat aktif dalam proses pembelajaran serta siswa dapat mengembangkan seluruh kemampuan yang ada pada dalam dirinya. Hal ini sejalan dengan UU No. 20 tahun 2003 tentang sistem pendidikan nasional, bahwa pendidikan adalah usaha sadar dan terencana untuk mewujudkan suasana belajar dan proses pembelajaran agar peserta didik secara aktif mengembangkan potensi dirinya untuk memiliki kekuatan spiritual keagamaan, pengendalian diri, kepribadian, kecerdasan, akhlak mulia, serta keterampilan yang diperlukan dirinya, masyarakat, bangsa dan negara.

Di setiap jenjang pendidikan khususnya di Sekolah Dasar, peserta didik diharuskan menempuh sejumlah mata pelajaran tertentu, 
diantaranya adalah mata pelajaran Bahasa Indonesia.

Menurut Rahmat (2017,hlm.29) menyatakan bahwa pembelajaran Bahasa Indonesia merupakan mata pelajaran yang menitikberatkan pada kompetensi berbicara, menulis dan membaca. Mata pelajaran Bahasa Indonesia Sekolah Dasar menuntut para siswa untuk dapat memahami konteks bacaan, sumber bacaan, kemampuan untuk berliterasi, kemampuan untuk menulis dan kemampuan dalam berbicara sesuai dengan kaidah dan ejaan yang tepat.

Ruang lingkup mata pelajaran Bahasa Indonesia mencakup komponen kemampuan berbahasa dan kemampuan bersastra yang meliputi aspek mendengarkan, menulis, membaca dan berbicara. Salah satu keterampilan yang sangat penting dikuasai oleh siswa adalah keterampilan membaca.

Menurut Yunus (2012,hlm.59) Jenis keterampilan membaca salah satunya adalah keterampilan membaca pemahaman. Menurut Tarigan (Putri Amma,2013,hlm. 856) membaca pemahaman (reading for undersanding) adalah jenis membaca untuk memahami standar-standar atau norma kesastraan, resensi kritis, drama tulis, dan pola-pola fiksi dalam usaha memperoleh pemahaman terhadap teks, pembaca menggunakan strategi tertentu. Keterampilan membaca pemahaman bukan hanya sekedar asal membaca saja akan tetapi harus didasari dengan pemahaman akan makna atau isi dari bacaan baik yang tersirat maupun tersurat.
Organization For Economic Cooperation and Develpoment (OECD) melalui Program for International Student Assessment (PISA) dalam literasi membaca pada tahun 2015 menempatkan Indonesia pada urutan bawah yaitu menempati posisi ke 63 dari 72 negara yang berpartisipasi. Baik tahun 2012 ataupun 2015, hasil nilai literasi membaca yang di peroleh Indonesia masih dibawah rata-rata skor 500 dari nilai yang ditetapkan PISA. Yaitu hanya mencapai Low Internasional Bencmark. (OECD,2015,hlm.5). Selain literasi membaca Indonesia yang masih tergolong rendah, kemampuan membaca anak Indonesia khususnya siswa Sekolah Dasar kelas IV masih juga tergolong rendah. Hal ini terbukti berdasarkan studi yang dilakukan Progress in International Reading Literacy Study (PIRLS) pada tahun 2011, menunjukan hasil bahwa kemampuan membaca siswa SD/MI kelas IV di Indonesia tergolong rendah, hanya 5\% siswa Indonesia yang diteliti menunjukan kemampuan membacanya sampai tingkat high dan advance, sementara lebih dari 30\% tingkatannya very low, hampir $40 \%$ hanya tingkat low dan bahkan hanya $25 \%$ saja siswa yang mencapai tingkat intermediate. (Wawan Krimanto,2015,hlm. 235) Artinya berdasarkan studi yang dilakukan oleh PISA dan PIRLS bahwa literasi membaca dan kemampuan membaca pemahaman masih jauh dari apa yang diharapkan. Oleh karena itu pengembangan kompetensi dalam aspek membaca perlu diperhatikan salah satunya dengan 
menggunakan beragam metode pembelajaran yang disesuaikan dengan karakteristik siswa.

Pelaksanaan pembelajaran Bahasa Indonesia perlu dirancang dengan berorientasi pada kemampuan menulis, membaca dan berbicara. Kemampuan tersebut menuntut siswa untuk bersikap ilmiah dalam memahami dan menyelesaikan permasalahan. Bahasa Indonesia merupakan salah satu mata pelajaran yang dianggap kurang menarik oleh kalangan siswa Sekolah Dasar. Sebagian diantara siswa Sekolah Dasar tidak menyukai mata pelajaran Bahasa Indonesia dikarenakan faktor strategi pembelajaran yang dilakukan guru kurang inovatif. Strategi yang inovatif dan kontrstuktif akan mampu memberikan wawasan pengetahuan siswa serta meningkatkan aktivitas dan kreativitas siswa dalam proses pembelajaran. Selain dari itu, dalam kegiatan aktivitas membaca tentunya siswa harus terlebih dahulu mempunyai minat terhadap membaca agar kemampuan siswa dalam memahami isi atau makna terhadap suatu bacaan akan lebih optimal.

Minat baca adalah "perhatian atau kesukaan (kecenderungan hati untuk membaca), yang mana minat akan membaca perlu dipupuk, dibina, diarahkan, dan dikembangkan dari sejak usia dini, remaja, sampai usia dewasa yang melibatkan peranan orang tua, masyarakat, dan sekolah. (Idris Karimah,2002,hlm.5).

Minat merupakan aspek kepribadian yang sangat mempengaruhi terhadap perilaku seseorang. (Amiliya Setiya Rina Harsono,
2012, hlm 57) Maka dari itu minat baca memang sangat penting untuk dimiliki oleh siswa karena nantinya siswa akan merasa terdorong dan mempunyai hasrat yang tinggi untuk membaca dengan tujuan untuk mendapatkan informasi serta pengetahuan. Akan tetapi minat baca akan terbentuk apabila siswa sudah mempunyai kemampuan membaca, karena pada dasarnya aspek keterampilan membaca merupakan penunjang keberhasilan dalam proses pembelajaran sehingga tujuan pembelajaran dapat tercapai secara optimal.

Untuk menumbuhkan kemampuan membaca pemahaman siswa disertai dengan minat baca siswa yang mumpuni maka perlu adanya strategi yang relevan yang dapat dijadikan suatu solusi untuk pemecahan masalahnya. Penerapan metode pembelajaran yang relevan dengan kebutuhan dan karakteristik siswa sekolah dasar yang operasional konkrit dapat mampu memebrikan proses pembelajaran yang efektif, maksimal dan optimal sehingga tujuan pembelajaran dan penelitian dapat tercapai dengan maksimal.

Scramble berasal dari bahasa Inggris yang diterjemahkan dalam bahasa Indonesia yang memiliki arti perebutan, pertarungan, dan perjuangan. Model pembelajaran scramble merupakan model pembelajaran yang mengajak siswa untuk menemukan jawaban dan menyelesaikan permasalahan yang ada dengan cara membagikan lembar kartu soal dan jawaban yang disertai dengan alternatif 
jawaban yang tersedia. (Shoimin, 2016,hlm.160)

Pembelajaran kooperatif tipe scramble merupakan salah satu model pembelajaran yang melibatkan beberapa siswa dalam kelompok untuk bekerja sama menjawab pertanyaan yang diajukan oleh guru dengan cara menyusun huruf menjadi kata, kata menjadi kalimat, atau kalimat yang teracak menjadi sebuah paragraf yang utuh dan bermakna. ( Sudarmi, 2017,hlm. 73)

Berdasarkan beberapa pengertian tersebut dapat diartikan bahwa model pembelajaran scramble merupakan model pembelajaran kelompok yang menekankan konsep belajar sambil bermain, karena model ini menggunakan kartu-kartu seperti kartu huruf, kartu kalimat, dan kartu paragraf sehingga siswa dalam kelompok berusaha memecahkan permasalahan dengan menggunakan kartu tersebut. Berdasarkan hal tersebut penerapan metode ini akan lebih memberikan kesempatan kepada siswa untuk terlibat aktif, sosialisasi, interaktif dan melakukan komunikasi antar siswa. berdasarkan hal tersebut maka disamping memberikan peningkatan terhadap kemempuan membaca pemahaman siswa, juga dapat memberikan peningkatan dan pengaruh bagi kecerdasan interpersonal dalam diri siswa.

Adapun langkah-langkah metode scramble yang perlu dilakukan adalah sebagai berikut:

a. Guru menyiapkan sebuah wacana, kemudian keluarkan kalimat-kalimat yang terdapat dalam wacana tersebut ke dalam kartu-kartu kalimat

b. Guru membuat kartu soal beserta kartu jawaban yang diacak nomornya sesuai materi bahan ajar teks yang telah dibagikan sebelumnya dan membagikan kartu soal tersebut

c. Siswa dalam kelompok masing-masing mengerjakan soal dan mencari kartu soal untuk jawaban yang cocok, sebelumnya jawaban telah diacak sedemikian rupa

d. Siswa diharuskan dapat menyusun kata jawaban yang telah tersedia dalam waktu yang ditentukan

e. Setelah selesai mengerjakan soal, hasil pekerjaan siswa dikumpulkan dan dilakukan pemeriksaan. (Bahri, 2006,hlm.90-91)

\section{METODE}

Metode yang digunakan dalam penelitian ini adalah metode eksperimen dengan rancangan desain Treatment by level 2 X 2 . Metode penelitian eksperimen dapat diartikan sebagai metode penelitian yang digunakan untuk mencari pengaruh perlakuan tertentu terhadap yang lain dalam kondisi yang terkendalikan. Metode eksperimen dengan variabel terikat adalah Kemampuan Membaca Pemahaman (Y). Penelitian ini dilakukan perlakuan (treatment) untuk mencari pengaruh di antara dua variabel yaitu variabel perlakuan adalah metode pembelajaran $\left(\mathrm{X}_{1}\right)$ dan variabel moderator adalah minat baca siswa $\left(\mathrm{X}_{2}\right)$. Variabel perlakuan adalah metode pembelajaran yang terdiri atas dua yaitu 
metode scramble dan metode ekspositori $\left(\mathrm{X}_{1}\right)$. Variabel moderator adalah minat baca ada dua yaitu minat baca tinggi dan minat baca rendah $\left(\mathrm{X}_{2}\right)$.

Penelitian ini menggunakan metode pembelajaran. Percobaan dilakukan kepada dua kelompok siswa yakni kelompok minat baca tinggi dan kelompok minat baca rendah mendapat perlakuan dengan pemberian metode scramble dan kelompok minat baca tinggi dan kelompok minat baca rendah mendapat perlakuan dengan metode ekspositori rancangan dalam penelitian ini terlihat pada Tabel 1 sebagai berikut:

Tabel 1

Rancangan treatment by level $2 \times 2$

\begin{tabular}{|c|c|c|}
\hline \multirow{2}{*}{ Minat Baca } & \multicolumn{2}{|c|}{ Variabel Perlakuan (A) } \\
\cline { 2 - 3 } & Metode & Metode \\
& Scramble (A1) & Ekspositori \\
& & (A2) \\
\hline Tinggi (B1) & A1B1 & A2B1 \\
\hline Rendah (B2) & A1B2 & A2B2 \\
\hline
\end{tabular}

Sugiyono (2010:215) mengemukakan bahwa sampel adalah sebagian dari populasi. Teknik penarikan sampel dalam penelitian ini menggunakan simple random sampling yang menurut Soewadji (2012: 137) yaitu suatu cara atau teknik pengambilan sampel dari populasi dengan cara random atau acak sederhana.

Sampel dalam penelitian ini adalah siswa kelas IV SD Negeri 1 Kawali dengan unit sample dipilih kelas IVA sebagai kelas eksperimen yang akan diberikan perlakuan dengan menggunakan model problem based learning sebanyak 30 siswa, sedangkan kelas IVB dipilih sebagai kelas kontrol yang belajar menggunakan metode ekspositori sebanyak 30 siswa.

Selanjutnya pada angket minat baca ditentukan kelompok atas dan kelompok bawah. Siswa dikategorikan ke dalam kelompok minat baca tinggi apabila skor berada pada rentang $27 \%$ skor tertinggi. Kemudian siswa dikategorikan ke dalam kelompok minat baca rendah apabila skor minat baca berada rentang $27 \%$ terendah. 30 x $27 \%=8$ sampel.

\section{HASIL DAN PEMBAHASAN}

\section{Hasil}

\section{Perbandingan Kemampuan membaca pemahaman yang belajar menggunakan Metode Pembelajaran Scramble dengan Metode Pembelajaran Ekspositori}

Berdasarkan hasil analisis varian (ANAVA) pada taraf signifikan $\alpha=0,05$, didapat $F_{\text {hitung }}=6,16>F_{\text {tabel }}=4,13$. Dengan demikian $\quad \mathrm{F}_{\mathrm{o}}>\mathrm{F}_{\mathrm{t}}$, sehingga $\mathrm{H}_{0}$ ditolak, sehingga dapat disimpulkan bahwa secara keseluruhan, terdapat perbedaan pengaruh yang signifikan antara kelompok siswa yang diberikan model scramble dengan kelompok siswa yang diberikan metode ekspositori terhadap kemampuan pemecahan masalah matematika. Oleh karena itu, kemampuan membaca pemahaman yang diberikan metode scremble ( $X=81,81$ dan $\mathrm{s}=8,28$ ) lebih tinggi secara nyata dibandingkan yang 
diberikan metode ekpositori $(X=79$ dan $\mathrm{s}=$ $5,86)$.

\section{Interaksi antara metode pembelajaran} dan minat baca siswa terhadap kemampuan membaca pemahaman. (INT A X B)

Hasil perhitungan ANAVA dapat diketahui bahwa nilai hasil pengujian hipotesis kedua yang disajikan dalam tabel ANAVA pada baris Interaksi A X B menunjukkan bahwa $\mathrm{H}_{0}$ ditolak berdasarkan nilai $\mathrm{F}_{\text {hitung }}=11,42>\mathrm{F}_{\text {tab }}(0,05: 1: 36)=4,11$ dengan demikian dapat diambil keputusan bahwa terdapat pengaruh interaksi yang signifikan antara metode pembelajaran dan minat baca siswa terhadap kemampuan membaca pemahaman siswa.

Data hasil penelitian, diperoleh skor ratarata kemampuan membaca pemahaman antara kelompok siswa yang memiliki minat baca tinggi yang diberikan metode scramble adalah sebesar 87,59 dan kelompok siswa yang memiliki minat baca rendah yang diberikan metode scramble adalah sebesar 78. Untuk skor rata-rata kemampuan membaca pemahaman antara kelompok siswa yang memiliki minat baca tinggi yang diberikan metode ekspositori adalah sebesar 75,14 dan kelompok siswa yang memiliki minat baca rendah yang diberikan metode ekspositori adalah sebesar 76,91.

Rangkuman hasil perhitungan data melalui ANAVA 2 X 2 dapat dilihat pada gambar interaksi sebagai berikut.

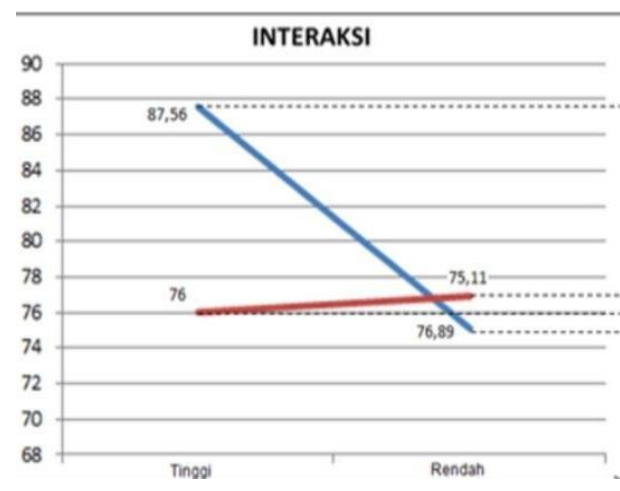

Gambar 1: Interaksi Metode Pembelajaran dan Minat Baca

\section{Keterangan :}

MBT S = Minat Baca Tinggi Menggunakan Metode Scramble

MBT Eks = Minat Baca Tinggi Menggunakan Metode Ekspositori

MBR PBL $=$ Minat Baca Rendah Menggunakan Metode Scramble

MBR Eks = Minat Baca Rendah Menggunakan Metode Ekspositori

\section{Perbedaan kemampuan membaca} pemahaman antara siswa yang belajar menggunakan metode pembelajaran Scramble dengan siswa yang belajar menggunakan metode ekspositori pada

kelompok siswa yang memiliki minat baca tinggi.

Perhitungan analisis varians tahap lanjut dengan Uji Tuckey adalah untuk membandingkan kelompok yang memiliki minat baca tinggi yang diberikan metode scramble dan yang diberikan metode ekspositori. Perhitungan Uji Tukey $\mathrm{A}_{1} \mathrm{~B}_{1}$ > $\mathrm{A}_{2} \mathrm{~B}_{1}=\mathrm{Q}_{\text {hitung }}=12,65$ lebih besar dari pada Qtabel 0,05:4:36= 4,07 atau $Q_{\text {hitung }}>Q_{\text {tabel }}$ pada taraf signifikan $\alpha=0.05$, dengan demikian $\mathrm{H}_{0}$ ditolak dan hipotesis alternatif $\mathrm{H}_{1}$ diterima. 
Sehingga dapat ditafsirkan kemampuan membaca pemahaman antara kelompok siswa yang diberikan model scramble lebih tinggi dibandingkan dengan kelompok siswa yang diberikan metode ekspositori. Oleh karena itu, bagi siswa yang memiliki minat baca tinggi yang diberikan metode scramble $\bar{X}=87,58$ dan $\mathrm{s}=6,18)$ lebih tinggi secara nyata dibandingkan yang diberikan metode ekspositori ( $\bar{X}=76 \mathrm{~s}=5,68)$.

\section{Perbedaan kemampuan membaca} pemahaman antara siswa yang belajar menggunakan metode pembelajaran Scramble dengan siswa yang belajar menggunakan metode ekspositori pada kelompok siswa yang memiliki minat baca rendah.

Perhitungan analisis varians tahap lanjut dengan Uji Tuckey adalah untuk membandingkan kelompok yang memiliki minat baca rendah yang diberikan metode scramble dan yang metode ekspositori. Perhitungan Uji Tukey

$\mathrm{A}_{1} \mathrm{~B}_{2}<\mathrm{A}_{2} \mathrm{~B}_{2}=\mathrm{Q}_{\text {hitung }}=-0,92$ lebih kecil dari pada $Q_{\text {tabel 0,05:4:36= 4,07 atau } Q_{\text {hitung }}<\text { Qtabel }}$ pada taraf signifikan $\alpha=0.05$, dengan demikian $\mathrm{H} 0$ ditolak dan hipotesis alternatif $\mathrm{H}_{1}$ diterima. Sehingga dapat ditafsirkan kemampuan membaca pemahaman antara kelompok siswa yang diberikan metode scramble lebih rendah dibandingkan dengan kelompok siswa yang diberikan metode ekspositori. Oleh karena itu, bagi siswa yang memiliki minat baca rendah yang diberikan metode scramble $\bar{X}=78$ dan s $=5,68$ ) lebih rendah secara nyata dibandingkan yang diberikan metode ekspositori $\bar{X}=76,90$ dan $\mathrm{s}=6,28)$.

\section{Pembahasan}

1. Perbandingan Kemampuan Membaca Pemahaman yang belajar menggunakan Metode Pembelajaran Scramble dengan Metode Pembelajaran Ekspositori

Siswa yang menggunakan metode Scramble menunjukan keaktifan dalam proses pembelajaran. Siswa menunjukan perilaku interaktif dan komunikatif antar siswa satu dan lainnya pada proses pemecahan masalah. Hal ini sesuai dengana apa yang diungkapkan Model pembelajaran scramble merupakan model pembelajaran yang mengajak siswa untuk menemukan jawaban dan menyelesaikan permasalahan yang ada dengan cara membagikan lembar kartu soal dan jawaban yang disertai dengan alternatif jawaban yang tersedia. (Shoimin, 2016,hlm.160).

2. Interaksi antara metode pembelajaran dan minat baca siswa terhadap Kemampuan membaca pemahaman. (INT A X B)

Penerapan metode Scramble berpengaruh pada peningkatan kemampuan membaca pemahaman. Melalui metode Scramble dalam proses pembelajaran membuat siswa belajar secara aktif, kratif interaktif dan komunikatif.

Siswa yang memiliki minat baca tinggi menunjukan aktivitas belajar yang interaktif, mengelola dan memecahkan masalah lebih baik serta menunjukan pola pikir yang lebih kritis aktif dan terkontrol dengan baik ketika 
berhadapan dengan masalah. Selanjutnya siswa yang memiliki minat baca tinggi dalam proses pembelajaran Scramble dapat mengontrol aktivitas belajar serta mampu memahami masalah disertai dengan strategi pemecahan masalah. Sebaliknya siswa yang memiliki minat baca yang rendah menunjukan kesulitan dalam mengontrol aktivitas belajar serta kesulitan dalam memahami dan memecahkan masalah yang dihadapi.

\section{Perbedaan kemampuan membaca} pemahaman antara siswa yang belajarmenggunakan metode

pembelajaran Scramble dengan siswa yang belajar menggunakan metode ekspositori pada kelompok siswa yang memiliki minat baca tinggi.

Metode Scramble dapat mendorong siswa memiliki kemampuan memecahkan masalah dalam situasi nyata, kemampuan membangun pengetahuannya sendiri melalui aktivitas belajar, Terjadi aktivitas ilmiah pada siswa melalui kerja kelompok dan memiliki kemampuan untuk melakukan komunikasi ilmiah dalam kegiatan diskusi atau presentasi hasil pekerjaan mereka. Siswa dengan minat baca tinggi dapat lebih cepat mengambil tindakan dalam setiap kegiatan belajarnya karena memiliki persiapan sebelumnya, sedangkan pada siswa dengan minat baca tinggi melalui metode ekspositori kurang dapat mengatur aktivitas belajarnya dikarenakan aktifitasnya diatur oleh guru.

Minat baca siswa dengan penerapan metode ekspositori hanya dapat menunjukan interaksi melalui proses tanya jawab saja tanpa adanya strategi pembelajaran yang memberikan kesempatan siswa untuk lebih aktif dalam kegiatan membaca. Pada dasarnya penerapan metode ekspositori hanya dilakukan oleh guru dengan tanpa memberikan kesempatan penuh kepada siswa untuk menemukan sendiri solusi pemecahan masalah kegiatan membaca. Selanjutnya dengan dengan minat baca tinggi melalui metode pembelajaran Scramble siswa mampu memahami masalah secara cepat, mampu menganalisis masalah, menggunakan strategi yang cepat dan tepat dalam proses pemecahan masalah, cepat dalam mengambil keputusan, selalu melakukan refleksi terhadap jawabannya, menunjukan kemampuan pemecahan masalah baik dengan penggunaan strategi pemecahan masalah berulang, serta dapat menyimpulkan solusi dari permasalahan yang ada.

\section{Perbedaan kemampuan membaca} pemahaman antara siswa yang belajar menggunakan metode pembelajaran Scramble dengan siswa yang belajar menggunakan metode ekspositori pada kelompok siswa yang memiliki minat baca rendah.

Kegiatan pembelajaran membaca yang dilakukan dengan metode pembelajaran Scramble merupakan pembelajaran dengan aktifitas yang berpusat pada siswa melalui tahapan berkelompok dalam memecahkan 
masalah kontektual pada pembelajarannya kontrol pembelajaran sepenuhnya berpusat pada siswa. Sedangkan pembelajaran ekspositori adalah pembelajaran dengan aktivitas verbal yang dilaksanakan guru kepada kepada siswa melalui strategi ceramah dan pemberian tugas, yang berarti kontrol pembelajar menjadi tugas guru sepenuhnya, sehingga siswa dengan metakognisi rendah dapat mengontrol aktivitas belajarnya lebih baik.

\section{SIMPULAN}

Penelitian ini menggunakan metode eksperimen yang melibatkan variabel bebas, yaitu metode scramble, metode ekspositori dan minat baca, sedangkan sebagai variabel terikatnya adalah kemampuan membaca pemahaman siswa SD Negeri 1 Kawali Kecamatan Kawali.

Berdasarkan hasil analisis data, hasil pengujian hipotesis dan hasil pembahasan penelitian yang telah diperoleh dijelaskan beberapa kesimpulan sebagai berikut:

1. Metode Scramble memiliki pengaruh yang lebih tinggi nilainya dari metode ekspositori terhadap kemampuan membaca pemahaman.

2. Terdapat interaksi antara metode pembelajaran dan minat baca terhadap kemampuan membaca pemahaman.

3. Siswa yang memiliki minat baca tinggi, kemampuan membaca pemahaman antara kelompok siswa yang diajar metode scramble lebih tinggi dari pada kelompok siswa yang diajar menggunakan metode ekspositori.

4. Siswa yang memiliki minat baca rendah, kemampuan membaca pemahaman antara kelompok siswa yang diajar menggunakan metode scramble lebih rendah dari pada kelompok siswa yang diajar menggunakan metode ekspositori.

\section{REFERENSI}

Amiliya Setiya Rina Harsono, Amir Fuady, Kundharu Saddhono, Pengaruh Strategi Know Want To Learn (KWL) Dan Minat Membaca Terhadap Kemampuan Membaca Intensif Siswa SMP Negeri Di Temanggung, Jurnal Penelitian Bahasa, Sastra Indonesia dan Pengajarannya, Volume 1 Nomor 1, April 2012, Universitas Sebelas Maret, h. 57

Aris Shoimin. 2014. 68 Model Pembelajaran Inovatif dalam Kurikulum 2013. Bandung: Ar Ruzz Media.

Bahri, S. Djamarah dan Aswan Zain. 2006. Strategi Belajar Mengajar. Jakarta: PT Rineka Cipta.

Idris Kamah, Pedoaman Pembinaan Minat Baca. (Jakarta: Perpustakaan RI, 2002), hal. 5

Organization Of Economic Cooperation And Development. Programme for International Student Assessment 2015 Result in Focus. (OECD:2015).

Putri Amma, Yosfan Azwandi, Markis Yunus, "Meningkatkan Kemampuan Membaca Pemahaman Pada Siswa Tunarungu Dengan Menggunakan Teknik Skimming," Jurnal Ilmiah Pendidikan Khusus; Volume 2, Nomor 3, September 2013 Pendidikan Luar Biasa, FIP UNP.

Rahmat. Games Book sebagai Media Peningkatan Minat Baca pada Pembelajaran Bahasa Indonesia SD Kelas Tinggi. Jurnal IJPE UPI, Vol 1 No 1 (2017) 27-33. 
Sugiyono. 2012. Metode Penelitian Kuantitatif Kualitatif dan $R \& D$. Bandunga: Alfabeta.

Sudarmi dan Burhanuddin. Keefektifan Model Pembelajaran Kooperatif Tipe Scramble Dalam Keterampilan Menulis Kalimat Bahasa Jerman Siswa Kelas XI SMA Negeri 11 Makassar.Jurnal Pendidikan Bahasa Asing dan Sastra, Volume 1, Nomor 1, Maret 2017, Universitas Negeri Makassar.

Undang-Undang Sistem Pendidikan Nasional No 20 tahun 2003. Jakarta: DEPDIKNAS.

Wawan Krimanto, Abdul Khalik, Sayidiman. "Meningkatkan Kemampuan Membaca Pemahaman Melalui Metode Survey, Question, Read, Recite, Review (SQ3R)," Jurnal Publikasi Pendidikan; Volume 5, Nomor 3, September 2015 PGSD UNM.

Yaumi. 2012.Pembelajaran Berbasis Multiple Intellegences. Jakarta: Dian Rakyat.

Yunus Abidin.2012. Pembelajaran Membaca Berbasis Pendidikan Karakter. Bandung: PT Refika Aditama.

Zulela. 2012.Pembelajaran Bahasa Indonesia. Bandung: PT Remaja Rosdakarya. 